\title{
SARGINIO LIMFMAZGIO NUSTATYMAS SERGANT MELANOMA. PIRMOJI KLAIPĖDOS UNIVERSITETINĖS LIGONINĖS PATIRTIS
}

\author{
Agnė Čižauskaitėi,2, Donatas Petrauskas ${ }^{1}$, Gintaras Gelžinis ${ }^{3}$, \\ Marija Sakalauskaité丶 ${ }^{3}$, Alvydas Česas ${ }^{1}$ \\ ${ }^{1}$ Klaipédos universitetiné ligoniné, Onkologijos chemoterapijos klinika \\ ${ }^{2}$ Klaipedos universitetas, Sveikatos mokslu fakultetas, \\ ${ }^{3}$ Klaipédos universitetinè ligoninè, Dienos, plastinès ir rekonstrukcinès chirurgijos skyrius
}

Raktažodžiai: melanoma, sarginis limfmazgis, limfodisekcija.

\begin{abstract}
Santrauka
Melanoma - piktybinè odos liga, pasižyminti didžiausiu mirtingumu tarp odos ligų. Sergamumas šia onkologine liga visame pasaulyje didèja. Chirurginis gydymas yra pagrindinis šios ligos gydymo metodas. Sarginio limfmazgio nustatymas IB ir II stadijos melanomos atveju yra neginčyjamas. Sarginio limfmazgio pašalinimas kelia daugybę diskusijų tam tikrų klinikinių situacijų atveju: melanomos lokalizacija galvos ar kaklo srityje, vyresnio amžiaus pacientai, „mažo storio“ melanoma, melanomai specifiškos komplikacijos, nerastas ir klaidingai neigiamas sarginis limfmazgis.

Klaipėdos universitetinèje ligoninejje atlikta 18 sarginio limfmazgio pašalinimo operacijų. Galvos srityje melanoma buvo nustatyta $3(16,67 \%)$ pacientams. Vyresni nei 65 metų dèl melanomos mūsų įstaigoje gydyti pacientai sudare $38,9 \%(\mathrm{n}=7)$ visu gydytų ligonių. Sarginis limfmazgis buvo nustatytas 6(37,5\%) „plona“ melanoma sirgusiems pacientams. Atliktų operacijų komplikacijų dažnis $11,11 \%(\mathrm{n}=2)$. Sarginiai limfmazgiai nebuvo nustatyti $2(11,11 \%)$ ligoniams.

Siekiant priimti tinkamiausią sprendimą nestandartinèse situacijose gydant melanoma sergančius ligonius, tikslingas multidisciplininis chirurgų, branduolinès diagnostikos gydytojų ir gydytojų patologų bendradarbiavimas.
\end{abstract}

Ivadas

Melanoma - piktybinė liga, dažniausiai pasireiškianti odoje, tačiau 5-10\% ligonių nustatoma akies tinklainejje ar ịvairios lokalizacijos gleivinèse (ryklès, makšties, išangès kt.) [1]. Nors ši onkologinè liga tesudaro $2,3 \%$ visu piktybinių odos ligų, pasižymi didžiausiu mirtingumu - net $75 \%$ tarp nustatytų odos vėžio atvejų. Visame pasaulyje sergamumas ja sparčiai didejja, per pastaruosius 30 metų moterims jis išaugo 4, o vyrams 7 kartus [2]. $2012 \mathrm{~m}$. Pasaulinès sveikatos organizacijos duomenimis, Europoje sergamumas siekè 11,1, o mirtingumas 2,3 atvejų 100.000 gyventojų, tuo tarpu Lietuvoje 7,0 ir 2,5 atvejų 100.000 gyventojų [3].

Chirurginis gydymas yra svarbiausias tiek pirminès, tiek ir lokaliai išplitusios melanomos atveju. Dažniausios šios ligos gydymui atliekamos operacijos yra plati naviko ekscizija, sarginio limfmazgio nustatymas ir sritinių limfmazgių pašalinimas (limfodisekcija) [4]. Sarginis limfmazgis (SLN) - pirmasis limfinio baseino, surenkančio limfą iš srities, kurioje lokalizuotas navikas, limfmazgis. Jo nustatymas ligoniui, sergančiam melanoma, pirmą kartą panaudotas $1992 \mathrm{~m}$. aplink naviką sušvirkštus metileno mèlio tirpalo ir operacijos metu nustačius mèlyna spalva nudažytą sarginị limfmazgị [5]. 1993 m. sarginiam limfmazgiui krūties vėžio atveju pažymèti buvo pirmą kartą panaudotas su radioaktyviojo technecio $99 \mathrm{~m}$-izotopu sujungtas baltymas, kuris operacijos metu buvo nustatytas sarginiame limfmazgyje naudojant nešiojamą gama jutiklị [6].

Sarginio limfmazgio nustatymas melanomos atveju yra svarbiausias prognostinis rodiklis [7]. Jis apibūdina sritinių limfmazgių būklę, svarbus stadijos nustatymui [8]. Regioninių limfmazgių būklè lemia adjuvantinio gydymo pasirinkimą. Sarginio limfmazgio nustatymas mažina lokalaus recidyvo dažnį. Remiantis MSLT-I studijos duomenimis, ligoniams su lokaliai išplitusia liga, kuriems buvo nustatytas teigiamas sarginis limfmazgis ir atlikta sritinè limfodisekcija, 10 metu išgyvenamumas be ligos buvo geresnis $(62,1 \%)$ nei ligonių, kuriems sritinè limfodisekcija buvo atlikta esant palpuojamoms metastazèms limfmazgiuose 
(41,5\%). Deja, statistiškai reikšmingo bendro išgyvenamumo padidejjimo nebuvo nustatyta [7]. Laukiama MSLT-II studijos duomenų, kurios metu tiriami ligoniai, kuriems nustatytas teigiamas sarginis limfmazgis, tačiau limfodisekcija neatliekama.

2015 m. NCCN klinikinès praktikos onkologijoje gairèse nurodyta, jog sarginio limfmazgio nustymas turi būti atliekamas ligoniams, kuriems diagnozuota IB ar II stadijos melanoma [9]. Nepaisant nustatytų ištyrimo ir gydymo protokolų, lieka keletas ginčytinų klinikinių situacijų, kuomet sarginio limfmazgio nustatymas išlieka individualus multidisciplininès komandos sprendimas. Straipsnyje išskyrėme keletą tokių situacijų ir panagrinejjome jas remdamiesi Klaipedos universitetinès ligoninès (KUL) Dienos, plastinès ir rekonstrukcinès chirurgijos skyriuje gydytu melanoma sergančių ligonių, kuriems buvo nustatytas sarginis limfmazgis, duomenimis. Pirmoji iš jų - melanoma esanti galvos ar kaklo srityje, taip pat vyresnio amžiaus pacientai, ,plona“ melanoma $(0.76-1.0 \mathrm{~mm}$ storio pagal Breslow), melanomai specifiškos komplikacijos, nerastas SLN ir klaidingai neigiamas SLN.

Darbo tikslas - atlikti retrospektyvinę ligonių, gydytų KUL Dienos, plastinès ir rekonstrukcinès chirurgijos skyriuje nuo $2014 \mathrm{~m}$. vasario mèn. iki $2015 \mathrm{~m}$. balandžio mèn., duomenų analizę.

\section{Medžiaga ir metodai}

Sarginio limfmazgio žymëjimas atliktas standartine technika naudojant ${ }^{99 m}$ Tc-NANOCOLL-40MBq. Tc99 buvo sušvirkštas aplink naviką i 2 - 4 kvadrantus vieną dieną prieš operaciją. Po radionuklido injekcijos visiems ligoniams buvo atlikta limfoscintigrafija Gama kamera Philips Bright View spect sistema (1 pav.). Scintigrafijos metu nustatytos SLN vietos branduolinès diagnostikos gydytojos

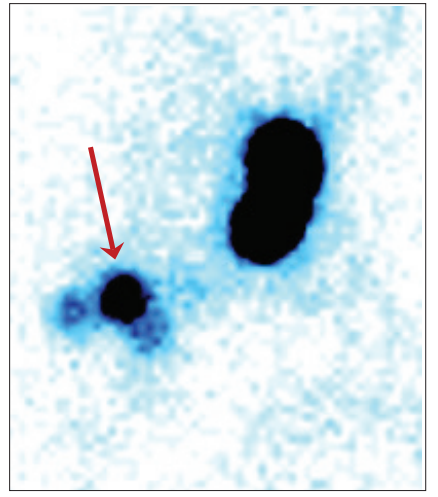

1 pav. Ausies kaušelio melanoma: scintigrafinis vaizdas (strèlytė žymi SLN)

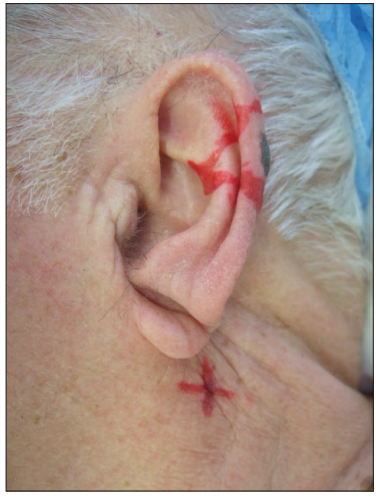

2 pav. Ausies kaušelio melanoma: SLN vietos pažymèjimas nenusitrinančiu rašikliu buvo pažymètos ant odos (2 pav.).

Kitą dieną po radionuklido sušvirkštimo ligoniai buvo operuoti, atliktos plačios darinio ar rando po buvusios biopsijos ekscizijos su ar be odos plastika kartu pašalinant $\gamma$ jutikliu nustatytus SLN. Rasti SLN buvo išsiųsti skubiam histologiniam ištyrimui, nustačius metastazę, buvo atlikta tos srities limfodisekcija.

\section{Rezultatai}

2014 m. vasario 3 d. KUL Dienos, plastinès ir rekonstrukcinès chirurgijos skyriuje pirmą kartą atliktas sarginio limfmazgio nustatymas odos melanoma sergančiai ligonei.

Nuo 2014 m. vasario mèn. iki 2015 m. balandžio mèn. atliktos 18 SLN nustatymo operacijos. $16(88,9 \%)$ iš jų dèl odos ir 2(11,1\%) dèl gleivinių melanomos.

Operacijos atliktos $7(38,9 \%)$ vyrams ir $11(61,1 \%)$ moterų. Bendras ligonių amžiaus vidurkis - 57,56(1883) metai. Pagal lokalizaciją navikai pasiskirsté: liemuo $[\mathrm{n}=5(27,9 \%)]$, viršutiné galūnè $[\mathrm{n}=5(27,9 \%)]$, apatinè galūnè $[n=3(16,7 \%)]$, galva ir kaklas $[n=3(16,7 \%)]$, makšties gleiviné $[\mathrm{n}=1(5,6 \%)]$, išangès gleivinè $[\mathrm{n}=1(5,6 \%)]$. $2(11,1 \%)$ ligoniams buvo nustatytos pooperacinès komplikacijos. Iš jų 1(5,6\%) SLN srities seroma ir 1(5,6\%) VII galvinio nervo pažeidimas. Vidutinè hospitalizacijos trukmè 2,2 (1-4) dienos.

1 lentelè. Odos melanomų hsitologinio tyrimo duomenys

\begin{tabular}{|l|c|}
\hline \multicolumn{1}{|c|}{ Analizè } & $\mathbf{N}(\%)$ \\
\hline Naviko dydis (pT) & $2(12,5 \%)$ \\
Tis & $4(25,0 \%)$ \\
T1a & $3(18,8 \%)$ \\
T2 & $2(12,5 \%)$ \\
T2a & $1(6,3 \%)$ \\
T2b & $4(25,0 \%)$ \\
T3 & $3(18,8 \%)$ \\
T3a & $1(6,3 \%)$ \\
T3b & $2(12,5 \%)$ \\
T4 & $1(6,3 \%)$ \\
T4a & $1(6,23 \%)$ \\
T4b & $1(6,3 \%)$ \\
Tx & \\
\hline Histologinis subtipas & $6(37,5 \%)$ \\
Paviršiumi plintanti & $3(18,6 \%)$ \\
Mazgine & $2(12,5 \%)$ \\
Lentigo maligna & $5(31,35 \%)$ \\
Nenurodyta & \\
\hline Išopėjimas & $1(6,3 \%)$ \\
Taip & $15(93,7 \%)$ \\
Ne & $12(75,0 \%)$ \\
\hline MTS in transit & \\
Taip & \\
Ne & \\
\hline
\end{tabular}


Remiantis galutinio histologinio tyrimo išvada nustatytos odos navikų $(\mathrm{n}=16)$ charakteristikos pateiktos 1 lentelëje.

Dažniausias operacijos metu nustatytu SLN skaičius buvo 2,27(1-6), iš jų daugiausiai $1[n=14(87,5 \%)]$ limfiniame baseine. 2 ligoniams buvo nustatyti 2(12,5\%) limfiniai SLN baseinai. Metastazès nustatytos 3(18,75\%) ligoniams, jų dydis svyravo nuo 0,1 iki 2,0 mm diametro. Ligonių, kuriems buvo nustatytos metastazès SLN duomenys aprašyti 2 lentelëje.

\section{Diskusija}

Dažniausiai melanoma pažeidžia galūnių ir liemens odą. Tai atitinka ir mūsų analizuotus duomenis - 13(72,3\%) ligonių, iš kurių 5(27,78\%) ši liga buvo diagnozuota liemens, $5(27,78 \%)$, viršutinès ir $3(16,67 \%)$ apatinès galūnès srityse. KUL gydytiems ligoniams melanoma galvos ir kaklo srityje buvo nustatyta $3(16,67 \%)$ pacientams, tai atitinka literatūroje nurodytus duomenis - 10-25\% [10]. Sarginis limfmazgis nebuvo nustatytas 1(33,33\%) ligoniui, literatūros duomenimis, sarginiai limfmazgiai nustatomi 90 - 96\% atvejų [11]. Didelis mūsų nenustatytų limfmazgių skaičius galèjo būti sąlygotas mažo atvejų skaičiaus. Sarginio limfmazgio nustatymas šiame regione dažnai yra sunkus dèl sudètingos ir nenuspejjamos limfinio drenažo sistemos su daugybiniais pirminiais nutekejjimo kanalais ir daugybi-

2 lentelè. Ligonių, kuriems buvo nustatytos metastazès SLN, analizè

\begin{tabular}{|l|l|l|l|}
\hline Analitė & Nr.1 & Nr.2 & Nr.3 \\
\hline $\begin{array}{l}\text { Ligonio charakte- } \\
\text { ristika }\end{array}$ & & & \\
Lytis & Moteris & Vyras & Moteris \\
Amžius (metai) & 57 & 53 & 65 \\
Naviko lokalizacija & Viršutine galūnė & Liemuo & Liemuo \\
\hline Naviko charakteristika & & & \\
Dydis & pT2 & pT3a & pTx \\
Storis pagal Breslow & 1,0 & 3,8 & 15,0 \\
(mm) & Taip & Ne & Ne \\
Išopejimas & Taip & Ne & Ne \\
Vertikalaus augimo & L0 V0 & L1V0 & L1 V1 \\
faze & & & \\
Limfovaskulinė & & & \\
invazija & & & \\
\hline Limfmazgiu & & & \\
charakteristika & & 1 & 2 \\
SLN skaičius & 1 & 1 & 1 \\
MTS SLN skaičius & 1 & 0,8 ir & 0,2 \\
MTS dydis (mm) & 2,0 & 0,1 & Ne \\
Limfodisekcija & Taip & Taip & - \\
MTS sritiniuose LN & $0 / 15$ & $0 / 10$ & \\
& & Ne & Taip \\
\hline MTS in transit & Ne & \\
\hline
\end{tabular}

niais sarginiais limfmazgiais [12]. Sarginių limfmazgių nustatymą palengvina dinaminè limfoscintigrafija, kuri buvo atlikta visiems mūsų pacientams. Kita problema, su kuria susiduriama šalinant limfmazgius galvos ir kaklo srityse, yra didelis radioaktyvus fonas, kuris kyla del greta sarginių limfmazgių esančio pirminio naviko. Fonui sumažinti autoriai siūlo sumažinti radioaktyvaus dažo kiekį, naudojant metileno mèli ar pirma atlikti pirmino naviko eksciziją [13]. Techniškai sudètingiausiais laikomi paausinès liaukos baseine, pasitaikančiame $32-33 \%$ ir priedinio stuburo nervo srityje lokalizuoti sarginiai limfmazgiai. Paausinès liaukos baseine esantys limfmazgiai dažniausiai yra maži ir pačios liaukos sudètyje, todèl, kai kurių autorių duomenimis, siekiant išvengti veidinio nervo pažeidimo, rekomenduojama paratiroidektomija [14]. Iki ketvirtadalio galvos ir kaklo sričiu melanomos atvejų nustatomas lokalus ligos recidyvas sarginio limfmazgio baseine, kas rodo dideli klaidingai neigiamų sarginių limfmazgių skaičių $[15,16]$. 1(33.33\%) ligoniui buvo nustatytas veidinio nervo pažeidimas. Remiantis literatūros duomenimis, esant galvos ar kaklo srities melanomai prieš operaciją rekomenduojama atlikti vieno fotono emisijos kompiuterinę tomografiją (SPECT-KT) [10].

Visuomenei senejjant, sergamumui melanoma didejjant vyresnių pacientų, tarp kurių naujai nustatomų melonomos atvejų skaičius didžiausias, gydymas tampa vis aktualesnis $[17,18]$. Vyresni nei 65 metų dèl melanomos mūsų ịstaigoje gydyti pacientai sudare $38.9 \%(\mathrm{n}=7)$ visų gydytų ligonių. Lyginant su jaunesniais melanoma sergančiais pacientais vyresnio amžiaus ligoniams rečiau nustatomas sritinių limfmazgių pažeidimas, tačiau sisteminio metastazavimo atvejų skaičius bei mirtingumas tarp jų yra didžiausias $[19,20]$. Literatūros duomenimis, tai gali būti dèka hematogeninio melanomos metastazavimo kelio [21]. Nepaisant to, vyresniems ligoniams dažnai neatliekamas sarginio limfmazgio nustatymas, taip pat sritinių limfmazgių limfodisekcija nustačius metastazę sarginiame limfmazgyje bei, net ir atliekant pilną sritinę limfodisekciją, retai pašalinama daugiau nei 10 limfmazgiu [22,23]. Vienas iš argumentu yra trumpa tikètina išgyvenamumo trukmè, kuri, manoma, gali būti trumpesnè nei galimas melanomos recidyvavimo laikas [19]. Remiantis literatūros duomenimis, 65-ių metų amžiaus žmogaus tikètinas išgyvenamumas šiandien yra 17-20 metų, o dažniausias melanomos recidyvavimo laikotarpis 2-3 metai [24]. Ligoniai, kuriems tuo metu bus tikslingas chirurginis ligos progresavimo gydymas, manoma, bus mažiau tinkami tiek operacijai, tiek bendrai anestezijai nei buvo ligos diagnozès metu [19]. Kitas svarus faktorius, nulemiantis redukuotą melanomos gydymą vyresniame amžiuje, yra dažnas netinkamumas adjuvantiniam 
gydymui ar ankstyvas jo nutraukimas, kuris taipogi daro sarginio limfmazgio nustatymo prasmingumą ligos stadizacijai bevertị [25]. Dažniausia priežastis, kodèl vyresnio amžiaus žemos rizikos pacientams nèra siūlomas sarginio limfmazgio nustatymas ar sritine limfodisekcija, nèra susijusi su komorbidine ligonio būkle, o chirurgo sprendimas šios operacijos neatlikti $[26,19]$. Todèl visiems ligoniams, vyresniems nei 65 -ių metų amžiaus, atlikus išsamų geriatrini įvertinimą, kurio metu būtų nustatytas jo socialinis, psichologinis, emocinis pasiruošimas operacijai, turetų būti atliktas melanomos gydymas pagal šiuo metu galiojanti protokolą [26].

Remiantis NCCN klinikinès praktikos onkologijoje gairemis, esant IA melanomos stadijai, dar vadinamai „mažo storio“ melanomai, kuomet naviko storis pagal Breslow 0,76-1,0 mm, sarginio limfmazgio nustatymas yra multidisciplininio gydytojų konsiliumo pasirinkimas [9]. Daugiau nei $70 \%$ visų naujai diagnozuojamų melanomų yra „plonos“ melanomos [27]. Mūsų duomenimis, sarginis limfmazgis buvo nustatytas 6(37,5\%), ,plona“ melanoma sirgusiems pacientams, iš kurių 2(12,5\%) galutinio histologinio tyrimo išvada - carcinoma in situ ir $4(25 \%)$ pT1a. Veiksniai, nulemiantys metastazès buvimą sarginiame limfmazgyje (teigiamas sarginis limfmazgis), yra Breslow storis, mitozių skaičius, išopejjimas, lygis pagal Clark, limfovaskuliné invazija, amžius, melanomos subtipas ir lokalizacija [28]. „Plonų“ melanomų mitozių skaičius dažniausiai yra žemas, o išopejjimas tesiekia 4-9\% atvejų, todèl 20 metų išgyvenamumas yra 96\% [29,30]. Teigiamas sarginis limfmazgis „mažo storio“ melanomų atvejų nustatomas $5,6 \%$ [31]. IA stadijos 0,75-1,0 mm melanomos metastazavimas ị sargini limfmazgi nustatomas $6,2 \%$, o storiui esant $<0,75 \mathrm{~mm}$ tik 2,7\% [32,33]. „Plonos“ melanomos nebuvo ịtrauktos ị MSLT-I studiją, kurios metu buvo lyginami „vidutinio storio“ melanoma sergantys ligoniai, kuriems buvo nustatomas sarginis limfmazgis ir esant metastazei atliekama sritine limfodisekcija, ir ligoniai, kurie buvo stebimi [7]. Todèl laukiama dviejų prospektyviniu studiju duomenu, tai - MSLT-2, kuri lygina ligonius su teigiamais sarginiais limfmazgiais, kuriems atliekama limfodisekcija ar stebejimas ir MINITUB, kurios metu norima nustatyti minimalų metastazès dydị, kurią nustačius limfodisekcija nebus atliekama. Sarginio limfmazgio nustatymas yra susijęs su didesniu mirtingumu ir dideliais procedūros kaštais, todèl svarbu nustatyti „mažo storio“ melanoma sergančius aukštos rizikos pacientus [31]. Pirminio naviko molekulinè charakteristika - biologiniai žymenys (mitozių skaičius, Ki-67, MCAM, metallotioneinas I ir II) galètų padèti diferencijuoti aukštos rizikos pacientus [34]. Aukštos raiškos ultragarsinio (UG), PET/KT tyrimai galètų būti alternatyva sarginio limfmazgio nustatymui žemos rizikos pacientams [35].

Po sarginio limfmazgio pašalinimo operacijų pasitaiko iki 10\% mažujų chirurginių komplikacijų, iš kurių reikšmingiausios: limfedema $-1 \%$, seromos susiformavimas - 5,5\%, žaizdos infekcija $-4,6 \%$ atvejų skaičiaus [7]. KUL atliktų operacijų komplikacijų dažnis $11,11 \%(n=2)$. Vienam ligoniui susiformavo žaizdos seroma, kurios kapsulè buvo pašalinta operaciniu būdu. Vienam pacientui po operacijos išryškejjo VII nervo pažeidimas. Esant vis didesniam sarginio limfmazgio pritaikymui melanoma sergantiems ligoniams literatūroje diskutuojama apie tikètinas ir ,priimtinas“ komplikacijas bei jų dažnị (3 lentelè) [36]. Nepaisant nedidelio KULgydytų ligonių skaitlingumo, tiek bendras komplikacijų dažnis, tiek ir pavienès melanomai specifiškos komplikacijos tik nežymiai viršija dažnį, nurodytą literatūros šaltiniuose.

Nepaisant radionuklidinio žymèjimo, limfoscintigrafijos ar chirurgo bei branduolinès diagnostikos gydytojo patyrimo, tam tikrais atvejais nepavyksta nustatyti sarginio limfmazgio. Limfmazgio identifikacijos dažnis priklauso nuo anatominès srities, kurioje jis lokalizuotas: kirkšninejje srityje jis nustatomas $99,3 \%$, pažastyje - 95,3\%, o kakle - 84,5\% [7,37]. Mūsų atliktų operacijų duomenimis, sar-

3 lentelè. Melanomai specifiškos komplikacijos (adaptuota pagal Read. et al. 2014)

Sutrumpinimai: $\mathrm{LTN}-n$. thoracis longus, $\mathrm{TDN}-n$. thoracodorsalis. Laužtiniuose skliaustuose pateikti KUL ligoninès duomenys.

\begin{tabular}{|l|l|c|}
\hline Analizė & & Siūlomas slenkstis \\
\hline $\begin{array}{l}\text { SLB srities infekcija } \\
\text { ar seroma }\end{array}$ & & $<5 \%[\mathrm{n}=1(5,56 \%)]$ \\
\hline CLND žaizdos revizija & Kaklo sritis & $<5 \%$ \\
\hline & Pažasties sritis & $<10 \%$ \\
\hline $\begin{array}{l}\text { CLND minimalus } 1 / \mathrm{m} \\
\text { skaičius }\end{array}$ & $\begin{array}{l}\text { Kirkšnies/ } \\
\text { Kubens sritis }\end{array}$ & $<30 \%$ \\
\hline & Kaklo sritis & $\geq 20$ \\
\hline & Kažasties sritis & $\geq 10$ \\
\hline $\begin{array}{l}\text { CLND kraujagyslių } \\
\text { pažeidimas su kraujo } \\
\text { netekimu }\end{array}$ & $\begin{array}{l}\text { Ileoingvinalinė } \\
\text { sritis }\end{array}$ & $<1 \%$ \\
\hline $\begin{array}{l}\text { Netyčinis nervo } \\
\text { paralyžius }\end{array}$ & VII laikinas & $<50 \%[\mathrm{n}=1(5,56 \%)]$ \\
\hline & VII nuolatinis & $<20 \%$ \\
\hline & XI, LTN, TDN & $<2 \%$ \\
\hline
\end{tabular}


giniai limfmazgiai nebuvo nustatyti $2(11,11 \%)$ ligoniams. Vienam iš jų melanoma buvo lokalizuota ausies kaušelyje, kitam - išangès srityje. Dažniausiai nustatomas sarginių limfmazgių skaičius yra 2,1-2,3 [38]. Tai atitinka KUL bendrą pašalintų limfmazgių skaičiu [2,27(1-6)]. Taipogi operacijos metu svarbu ivvertinti tarpinius limfinio drenažo baseinus. Literatūros duomenimis, pèdoje lokalizuotos melanomos sarginiai limfmazgiai $4 \%$ atveju nustatomi pakinklio, plaštakoje ir dilbyje esančių susirgimų atveju $-6,5 \%$ alkūnès srityje. Literatūros šaltiniuose nurodoma, jog limfoscintigrafinis sarginių limfmazgių žymèjimas nèra patikimas metodas sarginių limfmazgių skaičiui nustatyti, nes jos metu nurodytas limfmazgiu skaičius nekoreliuoja su operacijos metu pašalintų limfmazgių skaičiumi [39]. Jų identifikacijos dažnį iki 96 - 99\% pagerina dvigubo dažymo metodas kartu operacijos metu naudojant metileno mèli [37,38]. Kitas būdas pagerinti sarginių limfmazgių identifikacijos dažni melanomos atveju yra vieno fotono emisijos kompiuteriné tomografija (SPECT/KT) ar 18F-florodeoksigliukozès pozitrono emisijos tomografija (18F-PET/KT). Šie neinvaziniai tyrimo metodai leidžia topografiškai įvertinti tiriamą limfinį baseiną, tačiau turi mažą specifiškumą mažiems limfmazgiams ir yra brangūs $[40,41]$.

Kita aktuali problema susijusi su sarginių limfmazgiu nustatymu yra klaidingai neigiami sarginiai limfmazgiai. Klaidingai neigiamas sarginis limfmazgis patvirtinamas, kuomet pirmasis ligos recidyvas nustatomas sarginio limfmazgio baseine [42]. Bendras klaidingai neigiamų sarginiu limfmazgių dažnis, literatūros duomenimis, svyruoja iki $10 \%$, tačiau ilgalaikio ligonių stebejimo atveju jis aprašomas iki 25\% [7,8]. Didelis klaidingai neigiamų limfmazgių skaičius gali būti sąlygotas keleto priežasčių - chirurginių, branduolinès diagnostikos ir histologinio tyrimo netikslumo. Operacijos metu pašalinant tik „karščiausius“ limfinius mazgus, prarandama iki 20\% sarginių limfmazgių [43]. Literatūros šaltiniai rekomenduoja operacijos metu pašalinti visus limfmazgius, kurių radioaktyvus fonas didesnis nei $10 \%$,karščiausio“ limfinio mazgo [13]. Branduolinès diagnostikos gydytojo atliekama limfoscintigrafija sarginiams limfmazgiams nustatyti yra labai naudinga, tačiau ne visada tiksli priklausomai nuo suleisto radionuklido kiekio ar sutrikusio limfos nutekèjimo [44]. Todèl didejja vizualizacinių tyrimo metodų pritaikomumas melanoma sergančių ligonių atveju, ypač jei liga lokalizuota galvos ar kaklo srityje [41]. Literatūroje nurodyta, jog, esant lokaliam recidyvui sarginio limfmazgio baseine, pakartotinai ištyrus pašalintus sarginius limfmazgius daugumoje iš jų metastazès buvo rastos [42]. Histologiniam ištyrimui pagerinti diegiami nauji modernūs metodai - polimerazès grandininè reakcija (PGR) su melanoma susijusiems antigenams nu- statyti. Naudojant PGR metodą metastazès buvo nustatytos $12 \%$ sarginių limfmazgių, kurie pirmojo histologinio ištyrimo metu buvo laikomi neigiamais [8].

\section{Išvados}

Sarginių limfmazgių nustatymas sergant galvos ir kaklo srityje lokalizuota melanoma yra techniškai sudètingas, susijęs su dideliu komplikacijų bei klaidingai neigiamų limfmazgių nustatymo dažniu. Nustačius limfinio drenavimosi kelią per paausinę liauką, rekomenduojamas liaukos pašalinimas. Sudètingų neintervencinių vizualizacijos metodų (SPECT/KT, PET/KT) pritaikymas galètų sumažinti pooperaciniu komplikacijų bei klaidingai neigiamų limfmazgių skaičių. Vyrenių nei 65-ių metų amžiaus ligonių, sergančių melanoma, gydymo taktika neturètų skirtis nuo jaunesnių ta pačia patologija sergančių pacientų. Sprendimas neatlikti sarginio limfmazgio pašalinimo dažnai nesusijęs su gretutine patologija, yra nulemtas gydytojų sprendimo. Išsamus geriatrinis būklès ịvertinimas padètų nustatyti ligonius, kuriems sarginio limfmazgio nustatymo operacija būtu saugi. „Plonos“ melanomos atveju metastazavimo ị sritinius limfmazgius tikimybė yra maža, o išgyvenamumas sergant šia pradine melanomos forma yra didelis. Sarginio limfmazgio nustatymas turètų būti pasirinktas tik esant nepalankioms histologinèms melanomos charakteristikoms, kitu atveju rekomenduojama rinktis neinvazinius vizualizacinius metodus. Nustatytas su sarginio limfmazgio pašalinimu susijusių specifinių komplikacijų dažnis, kuris atitinka KUL atvejų skaičių. Negalint nustatyti sarginio limfmazgio, rekomenduojama įvertinti tarpinius limfinius baseinus, naudoti dvigubą limfmazgio žymèjimą ar rinktis instrumentinius vizualizacinius tyrimo metodus. Siekiant sumažinti klaidingai neigiamų limfmazgių skaičių, tikslinga pašalinti visus limfmazgius, kurių radioaktyvus fonas didesnis nei $10 \%$ „karščiausio“ limfinio mazgo. Glaudus bendradarbiavimas su branduolinès diagnostikos specialistais bei gydytojais patologais gali padèti išvengti klaidingai neigiamų limfmazgių nustatymo.

\section{Literatūra}

1. Khalil. DN. et al. Treatments for noncutaneous melanoma. Hematol Oncol Clin North Am 2014; 28(3):507-21.

http://dx.doi.org/10.1016/j.hoc.2014.02.006

2. Corrie P. et al. Management of melanoma. Br Med Bull 2014; 111(1):149-62.

http://dx.doi.org/10.1093/bmb/ldu019

3. Ferlay J. et al. Cancer incidence and mortality patterns in Europe: estimates for 40 countries in 2012. Eur J Cancer 2013; 49(6):1374-403.

http://dx.doi.org/10.1016/j.ejca.2012.12.027 
4. Read. et al. Quality assurance in melanoma surgery: The evolving experience at a large tertiary referral centre. Eur J Surg Oncol 2015;41(7):830-6.

http://dx.doi.org/10.1016/j.ejso.2014.12.003

5. Morton DL. et al. Technical details of intraoperative lymphatic mapping for early stage melanoma. Arch Surg1992;127(4):3929.

http://dx.doi.org/10.1001/archsurg.1992.01420040034005

6. Krag DN. et al. Surgical resection and radiolocalization of the sentinel lymph node in breast cancer using a gamma probe. Surg Oncol 1993;2(6):335-9; discussion 340. http://dx.doi.org/10.1016/0960-7404(93)90064-6

7. Morton DL. et al. Final trial report of sentinel-node biopsy versus nodal observation in melanoma. N Engl J Med 2014;370(7):599-609

http://dx.doi.org/10.1056/NEJMoa1310460

8. Karim RZ. et al. False negative sentinel lymph node biopsies in melanoma may result from deficiencies in nuclear medicine, surgery, or pathology. Ann Surg 2008;247(6):1003-10. http://dx.doi.org/10.1097/SLA.0b013e3181724f5e

9. NCCN. NCCN clinical practice guidelines in oncology. Melanoma v.1.2015. national Comprehensive Cancer Network: 2015.

10. Fitzgerald TL. et al. Patterns of node mapping differ for axial and extremity primary cutaneous melanoma: A case for a more selective use of pre-operative imaging. Surgeon 2015;3. pii:S1479-666X(14)00126-7.

11. Wagner JD. et al. Patterns of initial recurrence and prognosis after sentinel lymph node biopsy and selective lymphadenectomy for melanoma. Plast Reconstr Surg 2003;112(2):486-97. http://dx.doi.org/10.1097/01.PRS.0000070989.23469.1F

12. O'Brien CJ. et al. Prediction of potential metastatic sites in cutaneous head and neck melanoma using lymphoscintigraphy. Am J Surg 1995; 170(5):461-6.

http://dx.doi.org/10.1016/S0002-9610(99)80330-4

13. Carlson GW. et al. Sentinel lymph node biopsy in the management of cutaneous head and neck melanoma. Plast Reconstr Surg 2005;115(3):721-8. http://dx.doi.org/10.1097/01.PRS.0000152429.06593.C1

14. Eischer SA. et al. A prospective study of intraoperative lymphatic mapping for head and neck cutaneous melanoma. Arch Otolaryngol Head Neck Surg 2002;128(3):241-6. http://dx.doi.org/10.1001/archotol.128.3.241

15. Schmalbach CE. et al. Reliability of sentinel lymph node mapping with biopsy for head and neck cutaneous melanoma. Arch Otolaryngol Head Neck Surg 2003;129(1):61-5. http://dx.doi.org/10.1001/archotol.129.1.61

16. Patel SG. et al. Sentinel lymph node biopsy for cutaneous head and neck melanomas. Arch Otolaryngol Head Neck Surg 2002;128(3):285-91.

http://dx.doi.org/10.1001/archotol.128.3.285
17. Tsai S. et al. Epidemiology and treatment of melanoma in elderly patients. Nat Rev Clin Oncol 2010;7:148-52. http://dx.doi.org/10.1038/nrclinonc.2010.1

18. Lowe GC. et al. Increasing incidence of melanoma among middle-aged adults: an epidemiologic study in Olmsted County, Minnesota. Mayo Clin Proc 2014;89(1):52-9. http://dx.doi.org/10.1016/j.mayocp.2013.09.014

19. Sabel MS. et al. Sentinel Lymph Node Biopsy Use Among Melanoma Patients 75 Years of Age and Older. Ann Surg Oncol 2015;22(7):2112-9. http://dx.doi.org/10.1245/s10434-015-4539-7

20. Balch CM. et al. Age as a prognostic factor in patients with localized melanoma and regional metastases. Ann Surg Oncol 2013;20(12):3961-8. http://dx.doi.org/10.1245/s10434-013-3100-9

21. Chao C. et al. Correlation between prognostic factors and increasing age in melanoma. Ann Surg Oncol 2004;11(3):259-64. http://dx.doi.org/10.1245/ASO.2004.04.015

22. Bilimoria KY. et al. Complete lymph node dissection for sentinel node-positive melanoma: assessment of practice patterns in the United States. Ann Surg Oncol 2008;15(6):1566-76. http://dx.doi.org/10.1245/s10434-008-9885-2

23. Shah DR. et al. Age-related disparities in use of completion lymphadenectomy for melanoma sentinel lymph node metastasis.J Surg Res 2013;185(1):240-4.

http://dx.doi.org/10.1016/j.jss.2013.05.090

24. Heimann DM. et al. Surgical management of the older patient with cancer. In HurriaA, Balducci L (eds) Geriatriconcology: treatment, assessment and management. New York: Springer; 2009.

http://dx.doi.org/10.1007/978-0-387-89070-8_8

25 . Fleming NH. et al. Impact of age on the management of primary melanoma patients. Oncology 2013;85(3):173-81. http://dx.doi.org/10.1159/000351499

26. Grotz TE. et al. Management of regional lymph nodes in the elderly melanoma patient: patient selection, accuracy and prognostic implications. Eur J Surg Oncol. 2015;41(1):157-64. http://dx.doi.org/10.1016/j.ejso.2014.10.051

27. Montella A. et al. Cutaneous melanoma mortality starting to change: a study of trends in Northern Ireland. Eur J Cancer 2009;45(13):2360-6. http://dx.doi.org/10.1016/j.ejca.2009.03.004

28. Oliveira F. et al. The importance of mitosis as a factor for predicting sentinel lymph node biopsy for thin melanoma. An Bras Dermatol. 2011;86(4 Suppl 1):S107-9.

29. Balch CM. et al. Final version of 2009 AJCC melanoma staging and classification. J Clin Oncol 2009;27(36):6199-206. http://dx.doi.org/10.1200/JCO.2009.23.4799

30. Green AC. et al. Population-based 20-year survival among people diagnosed with thin melanomas in Queensland Australia. J Clin Oncol 2012;30(13):1462-7. 
http://dx.doi.org/10.1200/JCO.2011.38.8561

31. Warycha MA. et al. Meta-analysis of sentinel lymph node positivity in thin melanoma ( $\leq 1 \mathrm{~mm})$. Cancer 2009;115(4):869-79. http://dx.doi.org/10.1002/cncr.24044

32. Han D. et al. Clinicopathologic predictors of sentinel lymph node metastasis in thin melanoma. J Clin Oncol 2013; doi:10.1200/JCO.2013.50.1114 http://dx.doi.org/10.1200/JCO.2013.50.1114

33. Andtbacka RH. et al. Role of sentinel lymph node biopsy in patients with thin melanoma. J Natl Compr Canc Netw 2009;7(3):308-17.

34. Weinstein D. et al. Diagnostic and prognostic biomarkers in melanoma. J Clin Aesthet Dermatol 2014;7(6):13-24.

35. Hinz T. et al. Role of high-resolution ultrasound and PET/ CT imaging for preoperative characterization of sentinel lymph nodes in cutaneous melanoma. Ultrasound Med Biol 2013;39(1):30-6.

http://dx.doi.org/10.1016/j.ultrasmedbio.2012.08.024

36. Read RL. et al. In-transit melanoma metastases: incidence, prognosis, and the role of lymphadenectomy. Ann Surg Oncol 2015;22(2):475-81.

http://dx.doi.org/10.1245/s10434-014-4100-0

37. Carlson G. et al. Sentinel lymph node biopsy in the management of cutaneous head and neck melanoma. Plast Reconstr Surg 2005;115:721-8.

http://dx.doi.org/10.1097/01.PRS.0000152429.06593.C1

38. Stadelmann W. The role of lymphatic mapping and sentinel lymph node biopsy in the staging and treatment of melanoma. Clin Plast Surg 2010;37:79-99.

http://dx.doi.org/10.1016/j.cps.2009.08.001

39. Hudak KA. et al. Sentinel lymph node biopsy for melanoma: is there a correlation of preoperative lymphatic mapping with sentinel lymph nodes harvested? Ann Plast Surg 2015;74(4):462-6. http://dx.doi.org/10.1097/SAP.0b013e3182a1e544

40. Martínez-Menchón T. et al. Cost analysis of sentinel lymph node biopsy in melanoma. Actas Dermosifiliogr 2015;106(3):201-7. http://dx.doi.org/10.1016/j.ad.2014.10.009

41. Dellavedova L. et al. Missing sentinel lymph node in cutaneous melanoma. Indian J Nucl Med 2015;30(2):158-61. http://dx.doi.org/10.4103/0972-3919.152982

42. Clary BM. et al. Early recurrence after lymphatic mapping and sentinel lymph node biopsy in patients with primary extremity melanoma: a comparison with elective lymph node dissection. Ann Surg Oncol 2001;8:328-37. http://dx.doi.org/10.1007/s10434-001-0328-6

43. Veenstra HJ. et al. Less false-negative sentinel node proceduresin melanoma patients with experience and proper collaboration. J Surg Oncol 2011;104:606-11.

http://dx.doi.org/10.1002/jso.21967

44. Scolyer RA. et al. Failure to remove true sentinel lymph nodes can cause failure of sentine node biopsy technique: eveidence from antimony concentrations in false negative sentinel nodes from melanoma patients. Ann Surg Oncol 2004;11:174-8. http://dx.doi.org/10.1245/ASO.2004.11.912

\section{SENTINEL LYMPH NODE BIOPSY IN CASE OF MALIGNANT MELANOMA. FIRST EXPERIENCE OF KLAIPEDA UNIVERSITY HOSPITAL A.Čižauskaitè, D. Petrauskas, G. Gelžinis, M. Sakalauskaitė, A. Česas}

Key words: melanoma, sentinel lymph node, lymph node dissection.

Summary

Melanoma is a malignant cutaneous disease that has the highest mortality among all the cancers of the skin. The incidence of this malignancy is increasing worldwide. Sentinel lymph node biopsy for IB and II stage melanoma is established as a standard treatment. Though there is no overall consensus about sentinel lymph node biopsy in some clinical situations as melanoma located in the head or neck, elderly patients, thin melanoma, melanoma specific complications, unidentified and false-negative sentinel node.

18 sentinel lymph node biopsies for primary melanoma in Klaipeda University Hospital were performed. There were $3(16.67 \%)$ patients with melanoma of the head. $38.9 \%(n=7)$ of primary melanoma patients presented to our hospital were aged 65 years and older. Sentinel lymph node biopsies for 6(37.5\%) thin melanomas patients were performed. Complication rate was $11.11 \%(\mathrm{n}=2)$. There were no sentinel lymph nodes identified in $2(11.11 \%)$ cases.

In order to make the optimum decision in nonstandard clinical situation, the collaboration of surgeons, radionuclear medicine specialists and pathologists is obligatory.

Correspondence to: agne.cizauskaite@gmail.com

Gauta 2015-07-17 